\title{
Krzysztof Buchowski Polacy i Litwini między \\ (Uniwersytet w Białymstoku) marcem 1938 a wrześniem 1939 roku, czyli o tym, jak poznawano terra incognita
}

Drzez niemal dwie dekady, od akcji zajęcia Wilna przez generała Lucja1 na Żeligowskiego w 1920 roku do marca 1938 roku, Litwa i Polska nie utrzymywały oficjalnych stosunków międzypaństwowych. Granica była zamknięta, nie istniała komunikacja pocztowa, drogowa i kolejowa. Nie znaczy to, że kontakty całkiem ustały, były nawet niekiedy dosyć ożywione, przeważnie jednak nieoficjalne, w najlepszym wypadku - półoficjalne. Sporadycznie do Polski lub Litwy przyjeżdżali korespondenci prasowi, którzy w seriach artykułów na łamach czasopism kreślili mniej lub bardziej wiarygodny obraz odwiedzanego kraju i jego mieszkańców. Nadal był to jednak przekaz docierający do ograniczonego kręgu odbiorców. Z polskiej strony bywali w Kownie m.in.: Stanisław Kodź, Józef Mackiewicz, Tadeusz Katelbach, z kolei Warszawę i inne polskie miasta odwiedzali m.in.: Juozas Purickis, Jonas Pietrènas, Valentinas Gustainis.

$\mathrm{Na}$ skutek wzajemnej izolacji oraz niemożności konfrontacji wyobrażeń z rzeczywistością wiedza obu społeczeństw o najbliższym sąsiednim państwie pozostawała niewystarczająca. Następowało utrwalenie dawnych stereotypów i tworzenie nowych. Duża w tym zasługa państwowej propagandy, z reguły kreującej nieprzychylną wizję drugiej strony. Zwłaszcza na Litwie antypolska akcja propagandowa była bardzo nasilona.

Jak wyglądał obraz Polski i Polaków stworzony na użytek litewskiego społeczeństwa w okresie międzywojennym? W największym uproszczeniu: Polacy przez stulecia ciemiężyli i polonizowali Litwę, następnie, gdy 
Litwa wybijała się na niepodległość po pierwszej wojnie światowej, siłą zagarnęli jej stolicę - Wilno. Dlatego państwo litewskie nie utrzymywało kontaktu z Polską, czekając, aż krzywda zostanie naprawiona. Wileńszczyzna znajdowała się pod okrutną polską okupacją i była pogrążona w biedzie. Państwem polskim rządziła szlachta i oficerowie, gnębiło się w nim mniejszości narodowe. Ciężki był zwłaszcza los Litwinów i Ukraińców. Przemysł był słabo rozwinięty, gdyż Polacy nie potrafili dobrze gospodarować. Cecha ta wynikała z niedostatków polskiego charakteru narodowego ukształtowanego przez szlacheckie dziedzictwo.

Nie lepiej przedstawiał się wykreowany w Polsce wizerunek Litwy i Litwinów: Litwa przez stulecia pozostawała w braterskim związku z Polską i tak zapewne byłoby przez kolejne lata, gdyby nie garstka litwomanów, którzy z pomocą Rosji i Niemiec obałamucili naród i stworzyli marionetkowe państewko. Litwini niesłusznie domagali się Wilna, ponieważ większość mieszkańców miasta i regionu to Polacy. „Litwa kowieńska” prowadziła wrogą politykę, wychowując społeczeństwo w duchu nienawiści do wszystkiego, co polskie. W Kownie rządziła skorumpowana i nieudolna klika kierowana z Moskwy i Berlina. Kraj pogrążał się w kłopotach gospodarczych na skutek izolacji od Polski, a społeczeństwo cierpiało, oczekując pogodzenia się Kowna z Warszawą. Najwięcej krzywd musieli znosić miejscowi litewscy Polacy, poddani bezdusznym szykanom administracji. Równolegle z powyższym w polskiej świadomości stale funkcjonował zaczerpnięty z tradycji literackiej wizerunek sielskiej Litwy, pełnej nieprzebytych borów, łąk i pól, zamieszkanej przez dobry i łagodny, choć uparty, żmudzki lud.

W określonych warunkach trudno było o weryfikację wzajemnych wyobrażeń i stereotypów. Oba państwa i społeczeństwa były dla drugiej strony prawdziwymi terra incognita, chociaż ciekawość, co dzieje się „po tamtej stronie Niemna", była duża i wśród Polaków, i Litwinów. Przez stulecia kulturowej wspólnoty wytworzyły się bowiem liczne więzy, a kontakty zostały przerwane zaledwie kilkanaście lat wcześniej. Skąpe, na ogół sensacyjne i często bałamutne informacje jeszcze podsycały ciekawość.

W marcu 1938 roku w polskim Ministerstwie Spraw Zagranicznych uznano, że należy uczynić krok, który definitywnie przetnie gordyjski węzeł niecodziennego sporu. Pretekstu dostarczył incydent graniczny, w wyniku którego 11 marca zginął żołnierz Korpusu Ochrony Pogranicza. Do Kowna wysłano (17 marca) notę ultymatywną, w której polski rząd zażądał natychmiastowego nawiązania stosunków dyplomatycznych. Po krót- 
kim wahaniu, w nocy z 18 na 19 marca 1938 roku, Litwa przyjęła warunki. Wkrótce otwarto granicę, uruchomiono połączenia kolejowe i pocztowe. Uczyniono zatem pierwszy krok w kierunku normalizacji.

W Polsce atmosfera marcowego kryzysu była wyraźnie podgrzewana przez władze, jednak inicjatywę podchwyciła także część antysanacyjnej opozycji. Kampania propagandowa osiągnęła apogeum między 13 a 19 marca. W bardzo emocjonalnym tonie przedstawiano wówczas „Litwę kowieńską" jako wroga, sugerowano konieczność definitywnej rozprawy w celu przywrócenia normalnego stanu wzajemnych stosunków. Nie szczędzono przy tym patosu oraz ostrych sformułowań ${ }^{1}$.

Z inicjatywy władz w całej Polsce doszło do szeregu manifestacji, podczas których wzywano Naczelnego Wodza do podjęcia marszu na Kowno, skandowano: „My chcemy Kłajpedy!”, „Naród z armią na Litwę!”, „Biegiem Niemna maszerujemy do Bałtykowi!”, „Cała Litwa musi być nasza!”. Jednak obraz propagowany w czasie marcowego przesilenia został wykreowany wyraźnie w odpowiedzi na doraźne zapotrzebowanie, natomiast w niewielkim stopniu odzwierciedlał faktyczne nastroje większości polskiej opinii publicznej. Obserwatorzy dostrzegali, że wśród uczestników antylitewskich wieców dominował raczej nastrój pikniku i dobrej zabawy niż niechęci lub odwetu².

Przyjęcie warunków ultimatum przez Litwę, ogłoszone 19 marca, wywołało w Polsce uczucie ulgi i zadowolenia, jedynie narodowcy wytykali polskim władzom, że postawiły minimalistyczne żądania (jedynie nawiązania stosunków dyplomatycznych), i ubolewali nad zmarnowaną szansą na definitywne rozwiązanie kwestii litewskiej. Stronnictwo Narodowe próbowało nawet kontynuować antylitewską kampanię i zorganizować dalsze manifestacje, jednak tym razem akcja spotkała się ze stanowczym przeciwdziałaniem policji ${ }^{3}$. Władze wyraźnie dążyły do jak najszybszego zatarcia złego wrażenia, wywołanego eskalacją propagandy.

W prorządowej prasie na krótko zagościły triumfalizm i zachwyt nad skutecznością polskiej polityki. W kolejnych dniach i tygodniach ton publikacji na temat Litwy radykalnie się zmienił. Zdecydowana większość

\footnotetext{
${ }^{1}$ Zob. np.: „Ilustrowany Kurier Codzienny”, 17-20 III 1939; „Kurier Poranny”, 15 III 1938; „Kurier Warszawski”, 18 III 1938; „Polska Zbrojna”, 18-19 III 1938.

${ }^{2}$ Litwa przyjęła ultimatum, „Słowo”, 20 III 1938; por. L. Mitkiewicz, Wspomnienia kowieńskie 1938-1939, Warszawa 1990, s. 21-22.

3 Jak się szlachta mazowiecka wybierała na Litwę, „Warszawski Dziennik Narodowy”, 4 IV 1938; „Kurier Wileński”, 22 III 1938.
} 
czasopism, niedawno wzywających do marszu na Kowno, po 19 marca wychwalała Litwinów za podjęcie mądrej, odpowiedzialnej decyzji o ustępstwie. Porozumienie witano przypominaniem tradycji unii i braterstwa, ponownie nazywano Litwę „młodszą siostrą”, która powróciła na łono rodziny, już dużo mądrzejsza i bardziej doświadczona ${ }^{4}$. Minione dwudziestolecie waśni porównywano do fabuły Pana Tadeusza: „spory, niechęci, zatargi graniczne, grożące orężną rozprawą", ale w zakończeniu pojednanie i ,kochajmy się!’. Zaledwie w tle pojawiały się wątpliwości, czy po tak długim okresie antypolskiej nienawiści uparci Litwini rzeczywiście będą skłonni do prawdziwego porozumienia. Wszelkie zastrzeżenia zbywano jednak wszechobecnym optymizmem.

Również gazety wileńskie na ogół z zadowoleniem przyjęły zakończenie kryzysu. „Kurier Wileński” i „Słowo” chwaliły decyzję rządu litewskiego, traktując ją jako dowód politycznej suwerenności. Zdecydowanie na wyrost pisano o entuzjazmie, jaki wybuchł w Kownie po ogłoszeniu decyzji o nawiązaniu stosunków z Polską․ Należy zwrócić uwagę na wyraźną ewolucję postawy wobec Litwy ze strony zarówno „Kuriera”, jak i „Słowa”. W przypadku tej drugiej gazety można mówić wręcz o ,przekroczeniu Rubikonu" oddzielającego demonstrowaną przez lata niechęć od manifestacyjnej przyjaźni.

Reakcje litewskiego społeczeństwa w marcu 1938 roku były jednak jak najdalsze od entuzjazmu. Wśród Litwinów dominowały raczej uczucia niepokoju, gniewu, urażonej dumy oraz upokorzenia. Wieść o ultimatum i presja Polski dla wielu stanowiła wielki wstrząs. Nastroje części społeczeństwa, zwłaszcza narodowo usposobionej młodzieży, zrazu były bardzo wojownicze. W trosce o spokój władze usiłowały nie dopuścić do jakichkolwiek wystapień, które mogłyby sprowokować polską stronę Powszechnie wyrażano obawy o rzeczywiste intencje Polski. W analizach litewskich komentatorów niewspółmierne rozmiary reakcji na incydent graniczny dowodziły raczej zamiarów agresji i pozbawienia Litwy niepod-

${ }^{4}$ List do siostry, „Mucha”, 1938, nr 15; Litwo, ojczyzno moja..., „Ilustrowany Kurier Codzienny”, 20 i 26 III 1938; T. Katelbach, Pokój z Litwa, „Gazeta Polska”, 20 III 1938; J. Mak, Wyciagnięta dłoń do zgody, „Kurier Poranny”, 22 III 1938.

5 „Kurier Wileński”, 19 i 23 III 1938.

${ }^{6}$ J. Cicènas, Vilnius tarp audru, Chicago 1953, s. 351-352; L. Truska, Lietuva 1938-1953 metais, Kaunas 1995, s. 29-30; G. Janauskas, Jèga nèra teisè (1938 metu Lenkijos ultimatumas ir Lietuvos visuomene), „Darbai ir Dienos”, 2002, nr 30, s. 95-113. 
ległości ${ }^{7}$. Zbieżność czasowa $\mathrm{z}$ anszlusem, podobieństwo metod zastosowanych wobec Austrii i Litwy skłaniały litewską prasę do przypuszczeń, że Polska zawarła z Niemcami tajne porozumienie rozbiorowe w sprawie Litwy, akceptowane przez mocarstwa europejskie ${ }^{8}$. Bacznie zwracano jednak uwagę na wszelkie gesty dobrej woli z polskiej strony. Przykładowo - dostrzeżono, że po 20 marca warszawska prasa nie używa już nazwy „Litwa kowieńska”, pisząc w zamian Republika Litewska9. Pomimo to Litwini stale powątpiewali w szczerość polskich intencji. Jak twierdzono, Polacy muszą dopiero udowodnić dobrą wolę.

Nawiązując stosunki z Polską, litewskie władze musiały stale balansować między politycznymi realiami a nastawieniem opinii publicznej, generalnie nieprzychylnym Polsce. Mimo sugestii Warszawy, początkowo nie zamierzano rozwiązywać Związku Wyzwolenia Wilna (ZWW). W maju 1938 roku w kolejnej litewskiej konstytucji ponownie znalazł się zapis o Wilnie jako litewskiej stolicy. Podczas Narodowej Olimpiady Litewskiej, odbywającej się w lipcu w Kownie, reprezentacja Litwinów wileńskich była ostentacyjnie witana jako sportowcy z „Litwy okupowanej”. Na oficjalnym prospekcie mistrzostw Europy w koszykówce w Kownie w maju 1939 roku figurowała mapa, która nie uwzględniała już Kłajpedy (utraconej w marcu tego roku), ale Wileńszczyznę opisywała jako terytorium należące do Litwy. W trakcie meczu z gospodarzami drużyna Polski została wygwizdana, a z trybun rozlegały się ,wileńskie” hasła i pieśni ${ }^{10}$. Nie dało się wymazać skutków wielu lat intensywnej propagandy, tym bardziej że litewskiej władzy wcale nie zależało na przeprowadzaniu w społeczeństwie kampanii na rzecz zmiany sposobu postrzegania Polski i Polaków.

Niemal do końca 1938 roku litewska prasa nadal bardzo krytycznie wypowiadała się również o polityce zagranicznej Warszawy, utwierdzając wizerunek Polski jako agresora, sojusznika Niemiec i pseudomocarstwa z przerostem ambicji. Wyjątkowo złe wrażenie pozostawiło zajęcie Zaolzia w październiku 1938 roku, interpretowane jako współudział Polski

\footnotetext{
7 „Lietuvos aidas”, 14 i 19 III 1938; „Sekmadienis”, 3 IV 1938; „Trimitas”, 1938, nr 12.

8 „Lietuvos aidas”, 18 III 1938; „XX amžius”, 28 i 31 III 1938; „Lietuvos žinios”, 6 IV 1938; „Sekmadienis”, 10 IV 1938.

9 „Lietuvos žinios”, 25 III 1938.

${ }^{10}$ Lietuvos Centrinis Valstybès Archyvas (dalej: LCVA), f. 378, ap. 5, b. 3440, k. 36-39, Raport w sprawie działalności partii politycznych i organizacji społecznych, październik 1938; ibidem, ap. 10, b. 186, k. 166-269, Biuletyn Departamentu Bezpieczeństwa, 20 marca 1939.
} 
w rozbiorze Czechosłowacji. Karykaturzyści złośliwie komentowali brak zaproszenia Polaków na konferencję monachijską. Przykładowo - na rysunku zamieszczonym w tygodniku „Kuntaplis” symbolizująca Polskę postać w rogatywce oczekiwała jedynie na resztki ze stołu prawdziwych europejskich mocarstw ${ }^{11}$.

Symptomy rzeczywistej odwilży, przynajmniej w oficjalnych stosunkach między Polską a Litwą, pojawiły się dopiero jesienią 1938 roku, kiedy Litwa poczuła się zagrożona niemieckimi pretensjami w sprawie Kłajpedy. Władze zaczęły ostrożnie poszukiwać zbliżenia z Polską. Kowieński rząd zdecydował się na szereg gestów, które w Warszawie miały zostać jednoznacznie zinterpretowane. Zawarto układ handlowy. Nowym posłem mianowano Jurgisa Šaulysa, polityka dobrze postrzeganego przez Polaków. Po raz pierwszy od wielu lat zrezygnowano z organizacji centralnych obchodów rocznicy utraty Wilna, wyciszono antypolską propagandę w prasie, a 11 listopada 1938 roku kowieńskie gazety nadzwyczaj ciepło pisały o Polsce z racji Święta Niepodległości. Wreszcie 25 listopada litewski rząd zdecydował o rozwiązaniu $\mathrm{ZWW}^{12}$.

Jednakże wówczas polska strona nie była zainteresowana antagonizowaniem Niemców, dlatego nie podjęła inicjatywy Kowna w celu poważniejszego zbliżenia. Jedynie prasa wszystkich nurtów politycznych wyrażała solidarność z Litwą w jej staraniach o utrzymanie Kłajpedy i współczucie po utracie miasta w marcu 1939 roku $^{13}$.

Wszelako, gdy w kolejnych miesiącach 1939 roku wyraźnie pogorszyły się również stosunki niemiecko-polskie, tym razem to Warszawa próbowała zabiegać o pozyskanie sobie Kowna jako sojusznika. W ówczesnych polskich czasopismach coraz częściej dawano wyraz opinii, że polsko-litewskie przymierze zagwarantuje zwycięstwo nad wspólnym wrogiem. Chętnie nawiązywano przy tym do historii wspólnych zmagań z Krzyżakami, powoływano się na braterstwo broni pod Grunwaldem itp. W maju 1939 roku niemal z euforia przyjmowano w Polsce generała Stasysa Raštikisa, głównodowodzącego armii litewskiej. W jego wizycie dostrzegano przede wszystkim to, co chciano zobaczyć - finalizację oczekiwanego

\footnotetext{
11 „Kuntaplis”, 1938, nr 41.

12 „Lietuvos aidas”, 11 XI 1938; ,Trimitas”, 1938, nr 47.

13 „Kurier Wileński”, 24, 25 III i 9 IV 1939; „Warszawski Dziennik Narodowy”, 2 i 6 IV 1939; „Robotnik”, 3 IV 1939.
} 
sojuszu. Mimo wstrzemięźliwości Litwinów, do końca sierpnia w polskich gazetach wzywano ich do broni i wspólnej walki ${ }^{14}$.

W omawianym okresie również proces wzajemnego poznawania obu społeczeństw nie stał w miejscu. Otwarta granica, wznowienie komunikacji, dystrybucja zakazanej dotąd „zakordonowej” prasy, thumaczenia literatury pięknej oraz nowe publikacje na temat Polski i Litwy - sprzyjały zaskakującym odkryciom. Polacy dowiadywali się np., że Kowno jest drogim miastem, litewska wódka jest procentowo słabsza od polskiej, a Litwini są kulturalni i pracowici. Z kolei na litewskich scenach koncertowali polscy artyści. Prawdziwą furorę robiły polskie filmy. Mimo że nacjonalistycznie usposobiona młodzież niekiedy próbowała zakłócać seanse, w całej Litwie kina dosłownie pękały w szwach, zwłaszcza na Barbarze Radziwiłłównie, Znachorze, Czarnej perle oraz kilkunastu innych komediach i melodramatach $^{15}$.

Obie oficjalne agencje prasowe (polski PAT i litewska ELTA) akredytowały w Kownie i Warszawie swoich przedstawicieli, stale zasilających czasopisma licznymi korespondencjami. Autorem polskiego serwisu był Jerzy Drobnik, przebywający na Litwie od lipca 1938 roku. Jego teksty były wyważone, pozbawione cienia sentymentu wobec Litwy. Drobnik starannie unikał egzaltacji, nadal częstej wśród jego kolegów po piórze. Prezentował oceny litewskiej polityki wewnętrznej i zagranicznej wyłącznie z punktu widzenia polskiego interesu, rezygnując z pokazywania racji litewskich. W tym sensie jedynie w niewielkim stopniu przyczynił się do poznania nowoczesnej Litwy przez Polaków ${ }^{16}$. Znacznie więcej wnikliwych obserwacji, ale także dosyć nieoczekiwany ton zrozumienia i życzliwości, przyniosły drukowane na łamach „Słowa” korespondencje Józefa Mackiewicza, który bawił w Kownie w maju 1938 roku.

Stopniowe ocieplanie oficjalnych stosunków polsko-litewskich od przełomu 1938 i 1939 roku owocowało coraz częstszymi kontaktami i coraz

14 J. Kurek, Z nami! Inaczej zginiecie, „Ilustrowany Kurier Codzienny”, 14 VIII 1939; por. podobne apele: J. P., Nad litewskim morzem, „Polska Zbrojna”, 24 VIII 1939; Cat, Apel do Litwinów, „Słowo”, 30 VIII 1939.

${ }^{15}$ LCVA, f. 383, ap. 7, b. 2102, k. 443-444, Zestaw tytułów filmów, które mają zostać sprowadzone do litewskich kin, 6 kwietnia 1938; ibidem, b. 2014, k. 321, Raport policji z Wiłkomierza w sprawie zajść przed filmem Czarna perła, 17 marca 1939; „Słowo”, 24 IV 1938; „Kurier Wileński”, 22 I i 3 VI 1939.

16 Zob. np. korespondencję Jerzego Drobnika: „Kurier Poranny”, 12, 17 i 19 VII 1939; por. J. Drobnik, Pobyt i działalność w Kownie (od 10 lipca 1938 do 8 października 1939), „Zeszyty Historyczne”, 1974, nr 28. 
większą liczbą życzliwych publikacji po obu stronach. Jednak pod tym względem Polacy zdecydowanie przodowali. Kolejne miesiące przynosity coraz to nowe inicjatywy usiłujące przybliżyć polskiej opinii publicznej współczesną problematykę litewską. Władysław Wielhorski wydał monografię Litwa wspótczesna, a Wacław Nieciengiewicz obszerne, fachowe opracowanie poświęcone gospodarce Litwy ${ }^{17}$. W listopadzie 1938 roku ukazał się „litewski” numer miesięcznika dla młodzieży „Płomyk”, w którym zaprezentowano bardzo przychylny obraz Litwy, ugrzecznioną (politycznie poprawną - by użyć późniejszego terminu) wizję relacji polsko-litewskich. W tradycyjny sposób podkreślono natomiast historyczną wspólnotę i otwarcie nawiązano do wyobrażeń Litwy jako krainy puszcz, bagnisk, średniowiecznych legend i świętych dębów ${ }^{18}$. Na półkach księgarskich pojawiało się coraz więcej przekładów z litewskiej literatury, np. wysoko oceniona przez krytyków powieść Vincasa Mykolaitisa-Putinasa pt. W cieniu oltarzy. W 1939 roku w Warszawie opublikowano pokaźną Antologię literatury litewskiej, przygotowaną przez Julię Wichert-Kajruksztisową, a poprzedzoną entuzjastycznym wstępem profesora Konrada Górskiego.

Rolę prawdziwego adwokata Litwy przyjął „Kurier Wileński”, oferując czytelnikom bogaty zestaw tekstów na temat współczesnych problemów tego państwa. Słowami dosyć łagodnej krytyki komentowano jedynie brak swobód politycznych i nadal widoczną antypolskość. W superlatywach przedstawiano dorobek na polu gospodarczym i kulturalnym. Zdaniem „Kuriera” odkrycie osiagnięć Litwy powinno wzbudzić podziw Polaków i doprowadzić do przełamania stereotypu Litwina - zatwardziałego polonofoba. W jednym z numerów pisano: „W Polsce przyzwyczajono się wyobrażać Litwinów, jako takich sobie ludzi poczciwych, lecz z zabitym w głowy gwoździem antypolskim, parskających na samą myśl o Polsce i o jej kulturze, niszczących wszystko, co złego i dobrego otrzymali od Polski w kilkuwiecznym z nią współżyciu. I nikomu się nie śniło, że te zagwożdżone głowy mogą mieć nie tylko wysoką, ale w ogóle jakąkolwiek kulturę". Tymczasem, jak przekonywał autor powyższej wypowiedzi, odcięcie się od polskich wpływów było Litwinom potrzebne jedynie do obrony własnej tożsamości. Dzięki izolacji stworzyli imponujący gmach naro-

${ }^{17}$ W. Wielhorski, Litwa wspótczesna, Warszawa 1938; W. Nieciengiewicz, Litwa. Zarys gospodarczy, Warszawa 1939.

18 „Płomyk”, 1938, nr 10. 
dowej kultury. Obecnie, kiedy litewskość nie jest już zagrożona, chętnie powracają do swych korzeni, pragną duchowego dialogu z Polakami, którzy mentalnie i cywilizacyjnie są przecież Litwinom najbliżsi ${ }^{19}$. „Kurier” z podziwem, ale i zazdrością konstatował również, że w kwestiach ekonomicznych Litwa jest lepiej rozwinięta niż północno-wschodnia Polska, chwalił nawet osiagnięcia reformy rolnej, co jeszcze do niedawna wydawało się niemożliwe. Ukoronowaniem starań dziennika było wydanie specjalnego numeru poświęconego Litwie (4 marca 1939 roku), mieszczącego liczne teksty publicystyczne, wywiady, a także dwujęzyczne ogłoszenia.

Kowieńska prasa pilnie śledziła wszelkie informacje na temat Litwy pojawiające się w Polsce. Stanowczo piętnowano te, które uznawano za obraźliwe lub powielające stereotypy, natomiast wielokrotnie doceniano przejawy życzliwości. Niektóre artykuły były nawet przedrukowywane.

Apogeum procesu wzajemnego poznawania przypadło na lato 1939 roku. W lipcu bawiły w Polsce różne litewskie delegacje, m.in. wycieczka kilkunastu dziennikarzy. Obok korespondencji powtarzających schematyczny obraz Polski, owocem wizyty stały się reportaże, w których dawano wyraz pozytywnemu zaskoczeniu (przy okazji świadczące również o zakorzenieniu negatywnego postrzegania Polski). Przykładowo, na łamach „Lietuvos žinios” Jonas Kardelis notował: „Muszę przyznać, że Polskę wyobrażałem sobie zupełnie inaczej. Inaczej pod względem zasobów ekonomicznych, życia gospodarczego, społecznego, a nawet politycznego. Ważne będzie stwierdzenie, że Polska jest bez porównania lepsza, doskonalsza i bardziej postępowa, aniżeli wielu Litwinów to sobie wyobraża"20.

Mimo stopniowej normalizacji stosunków międzypaństwowych, najbardziej drażliwa pozostawała kwestia położenia mniejszości narodowych. W tej sprawie oba rządy przyjęły taktykę wyczekiwania na kroki drugiej strony, dlatego w dziedzinie mniejszościowej nie doszło do zasadniczego przełomu. Zarówno w polskiej, jak i litewskiej prasie aż do końca sierpnia 1939 roku w dalszym ciągu ubolewano nad trudnym życiem rodaków

${ }^{19}$ F. Zahora, Uwagi o kulturze litewskiej, „Kurier Wileński”, 22 I 1939; por. J. C., Litwie brak opozycji, „Kurier Wileński”, 1 I 1939; W. Abramowicz, Ksiażki i wydawnictwa litewskie, „Kurier Wileński”, 12 II 1939.

${ }^{20}$ Cyt. za: „Kurier Warszawski”, 30 VII 1939; por. Archiwum Akt Nowych, Ministerstwo Spraw Zagranicznych, t. 6167, k. 1-2, Pismo Polskiego Instytutu Prawa Administracyjnego do MSZ w sprawie wizyty delegacji samorządowców litewskich, 7 lipca 1939; szerzej na temat echa wizyty litewskich dziennikarzy zob. np.: „Kurier Wileński”, 8 VII 1939; „Warszawski Dziennik Narodowy”, 11 VII 1939. 
za otwartą już granicą ${ }^{21}$. O ile litewskie opisy Warszawy, Gdyni, Krakowa, polskiej obronności czy postępów nauki często sprawiały wrażenie daleko posuniętego obiektywizmu (nietrudno doszukać się w nich nawet elementów pozytywnych), o tyle wrażenia z Wilna nadal były podawane niemal wyłącznie w ciemnych barwach ${ }^{22}$. Trudno było zmienić głęboko zakodowany sposób przedstawiania upadku Wileńszczyzny pod „polską okupacją".

W sierpniu 1939 roku do Republiki Litewskiej z rewizytą udała się wycieczka polskich pisarzy, wykładowców akademickich i dziennikarzy. Wizyta również była udana mimo zgrzytu, do którego doszło w kowieńskim Muzeum Wojska, gdzie grupa została przez niedopatrzenie uraczona porcją standardowej antypolskiej propagandy. Oburzeni uczestnicy wycieczki opuścili wówczas muzeum ${ }^{23}$. W publikowanych reportażach nieprzyjemny incydent schodził jednak na dalszy plan. Przeważał zachwyt nad nowa Litwą, niektórzy autorzy koncentrowali się przede wszystkim na odnajdywaniu śladów przeszłości i historycznych związków polsko-litewskich. Stąd obecność niemal rytualnych, stereotypowych opisów „typowych” krajobrazów sielskich wsi, przydrożnych krzyży, „,nianowłosych żmudzkich dziewcząt”, a także „wzruszającej biblijnej polszczyzny” tamtejszych rodaków, jakby żywcem przeniesionych z Potopu ${ }^{24}$. Jak widać, również w przypadku Polaków odejście od stereotypowego postrzegania rzeczywistości było utrudnione, jeśli w ogóle możliwe.

Latem 1939 roku w polskiej prasie przeważał zdecydowanie pozytywny obraz „Litwy kowieńskiej”. „Kurier Poranny” przekonywał opinię publiczną, że Litwini obecnie może nie tyle lubią Polaków, ile „na pewno ich szanują". Wyrażał przy tym pogląd, że z czasem być może powróci sympatia, na którą jednak trzeba zasłużyć, uznając litewski dorobek państwowotwórczy. Inni autorzy byli zdecydowanie mniej powściagliwi, zapewniając, że

${ }^{21}$ „Trimitas”, 1938, nr 19 i 40; Komu to na Litwie potrzebne, „Ilustrowany Kurier Codzienny”, 26 VII 1939; S. Piasecki, Kompleks wileński na Litwie, „Prosto z mostu”, 1939, nr 35 .

22 „Trimitas”, 1938, nr 16; „XX amžius”, 21 IV 1938.

23 „Kurier Wileński”, 14 VIII 1939; S. Piasecki, op. cit.

${ }^{24}$ S. R. D. [Stanisław Ryszard Dobrowolski], Nowy i mocny trzon życia. Litwa-piękny kraj chłopów, „Kurier Polski”, 8 VIII 1939; J. Kurek, Uśmiech jasnowłosej ze Żmudzi, „Ilustrowany Kurier Codzienny”, 11 VIII 1939; J. P., Litewskość - język i mistyka historyczna, „Polska Zbrojna”, 10 VIII 1939; idem, Krzyże, ikony i znicze, „Polska Zbrojna”, 18 VIII 1939; M. Wańkowicz, Za zgodę polsko-litewska, „Kurier Wileński”, 14 VIII 1939; J. Maśliński, Poznajemy Litwę, „Kurier Wileński”, 14 VIII 1939. 
Litwini już odrzucili bagaż najnowszej historii, nie widzą już w Polakach wrogów, wszyscy odwiedzający Litwę są witani entuzjastycznie, niemal noszeni na rękach. Jak w końcu sierpnia z przesadą przekonywał korespondent „Kuriera Warszawskiego”: „Pełno o nas jest w gazetach [...], niewątpliwie jesteśmy obecnie w modzie" 25 .

Już niebawem doświadczenia wojenne zmusiły Polaków i Litwinów do weryfikacji wielu spośród wzajemnych wyobrażeń, zarówno pozytywnych, jak i negatywnych.

\section{Poles and Lithuanians between March 1938 and September 1939, how terra incognita was cognited (summary)}

During the Interwar Period Poland and Lithuania did not maintain diplomatic relations. The border was closed. The isolation enhanced spreading untrue information about the other side, strengthened myths and stereotypes. The diplomatic relations were established only after the Polish ultimatum in March 1938. Then the border was opened. Since that moment Polish and Lithuanian public opinion gained the possibility to verificate the existing information. The press published numerous accounts describing the situation in Lithuania and Poland. Among Polish newspapers the most interested in the topic were: "Słowo" and "Kurier Wileński." In the Lithuanian press Poland was presented with admiration. However, in reference to the situation in the Vilnius area, Polish government was severely criticized. So far inaccessible Polish films became very popular in the Lithuanian cinemas. In Poland there were countless publications about Lithuania and the translations from the Lithuanian language. Since autumn 1938, owing to the imminent threat from Germany, more and more signs of Polish-Lithuanian political rapprochement appeared. Nevertheless, the alliance was not formed. The outbreak of the Second World War in September 1939 hindered the progress towards the normalization of the relations.

${ }^{25}$ Z. Czyżowski, Ulotników bałtyckich, „Kurier Warszawski”, 28 VIII 1939; M. Niedziałkowski, Polska i Litwa. Idziemy naprzód..., „,Robotnik”, 17 VIII 1939. 
(cC) $(9)$ 